\title{
Effect of tumour necrosis factor $\alpha$ on rat blastocyst growth and glucose metabolism
}

\author{
S. Pampfer, B. Moulaert, I. Vanderheyden, Y-D. Wuu and \\ R. De Hertogh*
}

Physiology of Human Reproduction Research Unit, University of Louvain, School of Medicine, UCL 5330, 53 Avenue Mounier, B-1200 Brussels, Belgium

\begin{abstract}
Tumour necrosis factor $\alpha$ (TNF- $\alpha$ ) synthesis has recently been described in the uterus during the preimplantation phase of pregnancy. The present study was undertaken to determine whether preimplantation embryos are a potential target for TNF- $\alpha$ in rats. First, the expression of TNF- $\alpha$ receptors by blastocysts was demonstrated by ligand binding assay with human ${ }^{125}$ I-labelled TNF- $\alpha$ and reverse transcription-amplification for the p60 receptor form. The functionality of these receptors was then assessed by incubating blastocysts with $3 \mathrm{nmol}$ mouse TNF- $\alpha \mathrm{l}^{-1}$ in vitro and determining their morphology and the number of cells after $24 \mathrm{~h}$. At that concentration, cell proliferation in blastocysts was inhibited by TNF- $\alpha$ but this was not accompanied by any change in the morphology of the embryos. Similar results were obtained when lower doses of TNF- $\alpha$ (30 and $300 \mathrm{pmol} \mathrm{l}^{-1}$ ) were tested. The rate of glucose consumption of rat blastocysts exposed to $3 \mathrm{nmol}$ TNF- $\alpha 1^{-1}$ was not altered when they were incubated with the cytokine for $4 \mathrm{~h}$, but the rate of glucose incorporation decreased over the same period. Our data indicate that rat blastocysts are responsive to physiological concentrations of TNF- $\alpha$ and that this cytokine has the potential to influence the preimplantation development of rats.
\end{abstract}

\section{Introduction}

It is almost 20 years since tumour necrosis factor $\alpha$ (TNF- $\alpha$ ) was first identified in the serum of immunologically challenged mice (Carswell ef al., 1975). Since that time researchers have been exploring the many pleiotropic activities that it assumes in a wide array of biological systems. The best-known actions of TNF- $\alpha$ include the rejection of transplanted tumours, reactions to inflammatory and immunological agents, and the development of the cachectic condition that accompanies chronic illness (Fiers, 1991; see Vassalli, 1992 for review). Although macrophages have been identified as the primary cellular source of TNF- $\alpha$ (Männel et al., 1980), many different tissues and cell types can synthesize this cytokine upon adequate stimulation (Giroir et al., 1992). Even more impressive are both the ubiquitous distribution of TNF- $\alpha$-specific receptors in virtually all organs and tissues (Goodwin et al., 1991; Lewis et al. 1991) and the spectrum of possible biological reactions to TNF- $\alpha$ at the cellular level. In vitro, this cytokine can stimulate the growth of fibroblasts (Vilcek ef al., 1986), repress the differentiation of myoblasts (Miller et al., 1988), elicit the secretion of ACTH by pituitary cells (Bernardini et al., 1990), inhibit the lipoprotein lipase activity in adipocytes (Price et al, 1986) and induce the degeneration of oligodendrocytes (Selmaj and Raine, 1988).

*Correspondence and reprint requests.

Received 5 October 1993
Considering the above observations, the recently reported indications that TNF- $\alpha$ might also play an important role in the regulation of the reproductive system are not surprising. In the female rat, local TNF- $\alpha$ synthesis has been described in the ovary (Roby and Terranova, 1989; Sancho-Tello et al., 1992) and the uterus (Yelavarthi et al., 1991). During the peri-implantation phase of pregnancy in this species, TNF- $\alpha$ is predominantly synthesized by the epithelial cells lining the uterine lumen and the decidualized cells adjacent to the implanted embryo (Yelavarthi et al., 1991). Although rat ovarian thecal cells (Zachow et al., 1992; Brännström et al., 1993) and rat placental trophoblasts (Hunt et al., 1989, 1990) have been identified as responsive to TNF- $\alpha$, it is still unclear whether the development of embryos could also be directly influenced by TNF- $\alpha$ before or at the time of implantation. Previous attempts to address this issue using mouse embryos have failed to detect any significant effect of TNF- $\alpha$ in vitro during the preimplantation and peri-implantation developmental phases unless very high concentrations were used (Hill et al., 1987; Haimovici et al., 1991; Wincek et al., 1991; Lachapelle et al., 1993). In the present study, we report that rat blastocysts express TNF- $\alpha$-specific receptors before their implantation, an absolute prerequisite for any biological effect of TNF- $\alpha$, and that when this cytokine is added at physiological concentrations to the culture medium in vitro it influences the rates of cell proliferation and glucose incorporation by the blastocysts. 


\section{Materials and Methods}

\section{Reagents}

Human recombinant ${ }^{125}$ I-labelled TNF- $\alpha$ and D- $\left[5-{ }^{3} \mathrm{H}\right] g$ lucose were purchased from Amersham (Bucks). Mouse recombinant TNF- $\alpha$ was purchased from Boehringer (Mannheim), and rabbit anti-mouse TNF- $\alpha$ polyclonal antibody from Calbiochem (San Diego, CA). Taq DNA polymerase used in PCR was obtained from Cetus Perkin Elmer (Emeryville). Earle's balanced saline solution (EBSS), Dulbecco's PBS and glucose-free Ham's F-10 medium were purchased from Gibco (Paisley), $\alpha-D(+)$-glucose and polyvinylpyrrolidone were from Sigma (St Louis, MO). Moloney murine leukemia virus (MMLV) reverse transcriptase was purchased from United States Biochemicals (Cleveland, $\mathrm{OH}$ ).

\section{Embryos}

Sexually mature male and female Wistar rats from our breeding centre were mated overnight and checked the next morning (day I of pregnancy) for the presence of a vaginal plug. On day 5, embryos at the blastocyst stage were recovered from the uterus by inserting a 26-gauge needle into the utero-tubal junction and gently flushing $0.4 \mathrm{ml}$ prewarmed Ham's F-10 medium through each uterine horn. Embryos from different litters were pooled before being randomly distributed among culture groups in batches of 8-10 embryos.

\section{Ligand binding}

The presence of TNF- $\alpha$ receptors at the cell surface of rat blastocysts was tested by radioligand binding assay (Paria and Dey, 1990) with ${ }^{125}$ I-labelled TNF- $\alpha$. Embryos were released from their zona pellucida with $0.4 \mathrm{~g}$ pronase $1^{-1}$ and allowed to recover from the enzymatic treatment for $2 \mathrm{~h}$ in EBSS supplemented with $1 \mathrm{mmol}$ glutamine $1^{-1}, 1 \mathrm{mmol}$ pyruvate $\mathrm{l}^{-1}, 3 \mathrm{~g} \mathrm{BSA}^{-1}, 100$ iu penicillin $\mathrm{ml}^{-1}$ and $100 \mu \mathrm{g}$ streptomycin $\mathrm{ml}^{-1}$. The blastocysts were then incubated for $30 \mathrm{~min}$ at $37^{\circ} \mathrm{C}$ with $70 \mathrm{pmol}{ }^{125} \mathrm{I}$-labelled TNF- $\alpha \mathrm{l}^{-1}$ (final specific activity was $600 \mathrm{Ci} \mathrm{mmol}{ }^{-1}$ ) in PBS containing $1 \mathrm{~g}$ BSA $1^{-1}$, washed repeatedly in ice-cold PBS with the same concentration of BSA, and fixed in $40 \mathrm{~g}$ paraformaldehyde $1^{-1}$ in PBS for $15 \mathrm{~min}$ before their transfer onto polylysine-coated slides. The preparations were cytospun at $45 \mathrm{~g}$ for $5 \mathrm{~s}$, dehydrated through increasing grades of alcohol and applied directly against an autoradiographic film (Davis et al., 1989). Control experiments were carried out in parallel with a 500 -fold molar excess $\left(35 \mathrm{nmol} \mathrm{l}^{-1}\right.$ ) of unlabelled TNF- $\alpha$ added to displace the radioactive probe.

\section{$m R N A$ analysis}

Total RNA was extracted from pools of 30 embryos in the presence of $20 \mu \mathrm{g}$ E. coli ribosomal RNA using a microadaptation of the guanidium isothiocyanate-phenol chloroform isolation method (Chomczynski and Sacchi, 1987), and reversetranscribed for $90 \mathrm{~min}$ at $37^{\circ} \mathrm{C}$ in a volume of $50 \mu \mathrm{l}$ with $80 \mu \mathrm{mol}$ random cDNA primers $1^{-1}$ and $100 \mathrm{iu} \mathrm{MMLV}$ reverse transcriptase per reaction (Pampfer et al., 1992). After enzymatic heat inactivation, $5 \mu \mathrm{l}$ of the reverse-transcribed sample was added to $95 \mu \mathrm{l}$ of PCR mixture containing $1 \mu \mathrm{mol}$ PCR primers $\mathrm{I}^{-1}$ and 5 iu Taq polymerase (Pampfer et al., 1992). Amplification consisted of 40 cycles of $94^{\circ} \mathrm{C}$ for $1 \mathrm{~min}$, $60^{\circ} \mathrm{C}$ for $2 \mathrm{~min}$ and $72^{\circ} \mathrm{C}$ for $3 \mathrm{~min}$. PCR primers complementary to nucleotides $287-307$ and $710-730$ of the cDNA sequence that encodes the p60 form of the rat TNF- $\alpha$ receptor (TNF- $\alpha$ Rp60) (Himmler et al., 1990) were designed to generate an amplicon of 444 basepairs (bp). On the basis of the great similarity $(78 \%)$ between rat TNF- $\alpha$ Rp60 and human TNF- $\alpha$ Rp55 cDNAs in the targeted region, and the possibility that their intron-exon structure may be conserved, it was assumed that the amplification of contaminating genomic DNA would produce a distinct amplicon. Preliminary amplification of DNA purified from rat uterine cells with the same TNF- $\alpha$ Rp 60 primers produced an amplicon of about $1100 \mathrm{bp}$ (data not shown). PCR primers complementary to nucleotides 184-203 and $405-424$ of the rat $\beta$-actin cDNA sequence (Nudel et al., 1983) were used in control reactions. The $\beta$-actin-specific primers generated an amplicon of $241 \mathrm{bp}$ from $\mathrm{cDNA}$ and 327 bp from genomic DNA. Total RNA from about $5 \times 10^{5}$ uterine cells (obtained by flushing the reproductive tract) was analysed in parallel for $\beta$-actin and TNF- $\alpha$ Rp60 mRNA expression. PCR reactions were subjected to electrophoresis on $2 \%$ agarose gels in the presence of $\mathrm{I} \mu \mathrm{mol}$ ethidium bromide $\mathrm{I}^{-1}$.

\section{Culture}

The culture medium was Ham's F-10 supplemented with $6 \mathrm{mmol}$ glucose $\mathrm{I}^{-1}, 1 \mathrm{mmol}$ glutamine $\mathrm{l}^{-1}, 1 \mathrm{~g}$ of either BSA or polyvinylpyrrolidone $\mathrm{I}^{-1}$ and antibiotics as above (De Hertogh et al., 1991) with or without TNF- $\alpha$. Incubations were carried out at $37^{\circ} \mathrm{C}$ in a humidified atmosphere with $5 \%$ $\mathrm{CO}_{2}$ for $24 \mathrm{~h}$. Control medium contained the same final concentration of TNF- $\alpha$ vehicle solution as did the TNF- $\alpha$ medium. During incubation, the embryo:volume ratio was maintained at one blastocyst per $25 \mu \mathrm{l}$ of medium. In some control experiments, the culture medium containing TNF- $\alpha$ was incubated with a 500-fold molar excess of neutralizing antiTNF- $\alpha$ antibody for $1 \mathrm{~h}$ at $37^{\circ} \mathrm{C}$ before use. The morphology of the blastocysts and the number of cells were determined at both the start and the end of the incubation time. The developmental stages were scored according to the following criteria: blastocyst with a nascent blastocoele, 7; blastocyst with clearly demarcated trophectoderm and inner cell mass, 8 ; expanded blastocyst with enlarging blastocoele, 9; hatching blastocyst, 10; and fully hatched blastocyst, 11 (Gates, 1965). The number of cells was estimated using a differential fluorochrome staining technique that allows for the separate counting of inner cell mass and trophectoderm cells in individual blastocysts (Pampfer et al., 1990). Embryos were denuded with $0.4 \mathrm{~g}$ pronase $\mathrm{l}^{-1}$, incubated for $30 \mathrm{~min}$ at $37^{\circ} \mathrm{C}$ in $10 \%$ rabbit anti-rat antiserum in EBSS and treated for $30 \mathrm{~min}$ at $37^{\circ} \mathrm{C}$ with $5 \%$ guinea-pig serum in EBSS to immunolyse the trophectoderm cells. This treatment resulted in the permeabilization of these cells to two DNA fluorescent dyes, bisbenzimide $\left(20 \mu \mathrm{g} \mathrm{ml}^{-1}\right)$ and propidium iodide $\left(10 \mu \mathrm{g} \mathrm{ml}^{-1}\right)$, whereas the Downloaded from Bioscientifica.com at 04/26/2023 11:30:40AM 
(a)

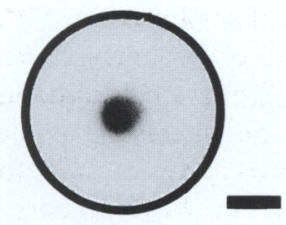

(b)

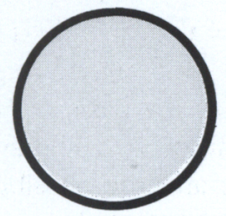

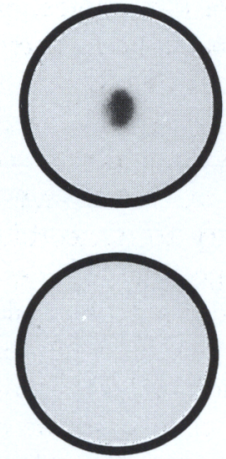
Fig. 1. Presence of tumour necrosis factor $\alpha$ (TNF- $\alpha$ ) receptors at the
cell surface of rat blastocysts. (a) Two blastocysts were incubated with cell surface of rat blastocysts. (a) Two blastocysts were incubated with
${ }^{125}$ I-labelled TNF- $\alpha$ and transferred onto glass slides before autoradiography. A positive signal was obtained for each embryo. The size of the spots was larger than that of the embryos owing to the diffusion of $\gamma$ particles into the film emulsion. (b) Two blastocysts were treated as above in the presence of a molar excess of unlabelled TNF- $\alpha$. No autoradiographic signal was obtained. Scale bar: $3 \mathrm{~mm}$.

inner cell mass was permissive to bisbenzimide only. Cells containing nuclear fragments were counted as dead cells and the dead cell index of each embryo was calculated in both inner cell mass and trophectoderm cell lineages as described by Pampfer et al. (1990).

\section{Glucose metabolism}

Groups of three blastocysts were placed in metabolic chambers in $5 \mu \mathrm{l} \mathrm{Ham}$ 's F-10 supplemented with $280 \mu \mathrm{mol}$ glucose $\mathrm{I}^{-1}, 1 \mathrm{~g} \mathrm{BSA} \mathrm{I}^{-1}, 25$ mmol Hepes $\mathrm{l}^{-1}$, antibiotics and D- $\left[5-{ }^{3} \mathrm{H}\right]$ glucose (final specific activity was $1.1 \mathrm{Ci} \mathrm{mmol}{ }^{-1}$ ) (Dufrasnes et al., 1993) with or without TNF- $\alpha$. Glucose consumption was measured after $4 \mathrm{~h}$ of incubation at $37^{\circ} \mathrm{C}$. Previous experiments have shown that about $82 \%$ of the ${ }^{3} \mathrm{H}_{2} \mathrm{O}$ released by rat blastocysts in $4 \mathrm{~h}$ were recovered in the $\mathrm{NaOH}$ chemical trap. At the end of the incubation, the embryos were recovered, washed and the amount of radiolabelled glucose that had been incorporated determined (Dufrasnes et al., 1993).

\section{Statistical analysis}

Statistical differences between control and TNF- $\alpha$ culture groups were analysed by unpaired Student's $t$ test or one-way analysis of variance, as appropriate. Comparisons between distributions of number of cells were carried out using the $\chi^{2}$ test.

\section{Results}

\section{TNF-a receptors}

The presence of TNF- $\alpha$ receptors was visualized at the cell surface of rat blastocysts by means of a radiolabelled ligandbinding technique (Fig. I). Autoradiographic signals for ${ }^{125} \mathrm{I}$ labelled TNF- $\alpha$ were repeatedly detected on these embryos and (a)

(b)

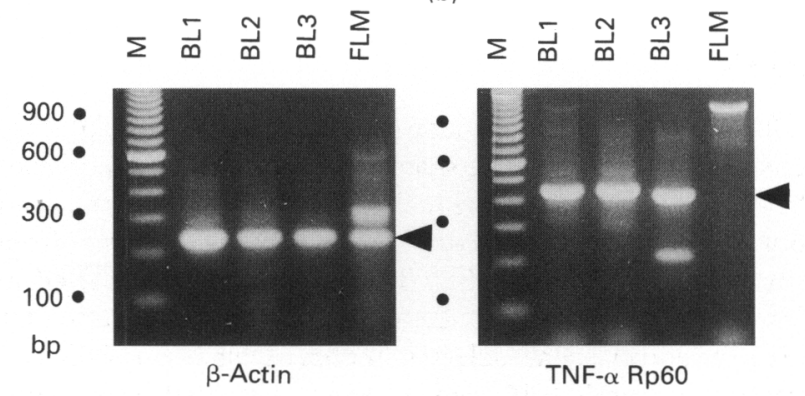

Fig. 2. Presence of mRNA transcripts for the p60 form of the tumour necrosis factor $\alpha$ (TNF- $\alpha$ ) receptor in rat blastocysts. (a) Total RNA from three different batches of about 50 embryos (BL) was reverse transcribed and amplified for rat $\beta$-actin. The expected $241 \mathrm{bp}$ amplicon (arrowhead) was visualized after electrophoresis. Total RNA from uterine cells present in the flushing medium (FLM) generated the same amplicon as well as a product probably derived from the amplification of genomic DNA. (b) The same blastocyst preparations were amplified for the p 60 form of the TNF- $\alpha$ receptor and produced the expected $444 \mathrm{bp}$ amplicon (arrowhead). No RNA specific amplicon was obtained from uterine cells but a product with the predicted size (about 1100 bp) of a genomic TNF- $\alpha$ Rp 60 amplicon was detected.

the binding of ${ }^{125}$ I-labelled TNF- $\alpha$ was completely displaced by the addition of a 500 -fold molar excess of unlabelled TNF- $\alpha$.

Blastocysts were then tested by reverse transcription and PCR for the presence of mRNA encoding the p60 form of the TNF- $\alpha$ receptor (Fig. 2). Total cDNA was prepared from three batches of embryos and first analysed using $\beta$-actin PCR primers. An amplicon of the predicted size for $\beta$-actin (241 bp) was generated using cDNA from all three embryo batches. CDNA prepared from uterine debris produced the same fragment and a larger product that was identified by its size as resulting from the amplification of contaminating genomic DNA. When TNF- $\alpha$ Rp60 primers were used in similar PCR reactions, they generated a 444 bp amplicon that was confirmed as deriving from the cDNA for TNF- $\alpha$ Rp 60 by restriction enzyme mapping (data not shown). No amplicon of this size was produced when total cDNA from uterine debris was amplified with the same set of TNF- $\alpha$ Rp60 primers, indicating that the positive reactions in the embryo cDNA samples were not due to the presence of contaminating uterine cells. A weak PCR band of about $1100 \mathrm{bp}$ was visible in the uterine cell cDNA sample analysed with the TNF- $\alpha$ Rp60 primers, and probably resulted from the amplification of genomic DNA present in that preparation.

\section{Embryo growth}

After $24 \mathrm{~h}$ of incubation, no significant difference was found in the morphology of blastocysts that were grown in the presence or absence of $3 \mathrm{nmol}$ TNF- $\alpha 1^{-1}$ (Table 1). In each culture group, about $65 \%$ of the blastocysts were expanded, $25 \%$ were in the process of hatching out of their zona pellucida and $10 \%$ were fully hatched. The morphological development of these embryos in the presence or absence of TNF- $\alpha$ was not modified when the medium was supplemented with polyvinylpyrrolidone instead of BSA. 
Table 1. Effect of $3 \mathrm{nmol}$ tumour necrosis factor $\alpha(\mathrm{TNF}-\alpha) \mathrm{l}^{-1}$ on the morphology of rat blastocysts incubated for $24 \mathrm{~h}$

\begin{tabular}{|c|c|c|c|c|c|c|}
\hline \multirow[b]{3}{*}{ Culture medium } & \multicolumn{6}{|c|}{ Morphological score } \\
\hline & \multicolumn{2}{|c|}{ At start of incubation } & \multicolumn{4}{|c|}{ At end of incubation $(24 \mathrm{~h})$} \\
\hline & Control & $\begin{array}{l}\text { Number } \\
\text { of embryos }\end{array}$ & Control & $\begin{array}{c}\text { Number } \\
\text { of embryos }\end{array}$ & TNF- $\alpha$ & $\begin{array}{l}\text { Number } \\
\text { of embryos }\end{array}$ \\
\hline Ham's F10 + BSA & $7.83 \pm 0.07$ & 29 & $9.40 \pm 0.13$ & 30 & $9.21 \pm 0.08$ & 29 \\
\hline Ham's F10 + PVP & $8.06 \pm 0.05$ & 49 & $9.28 \pm 0.06$ & 54 & $9.21 \pm 0.06$ & 52 \\
\hline
\end{tabular}

Results are given as means \pm SEM.

PVP: polyvinylpyrrolidone.

Table 2. Effect of $3 \mathrm{nmol}$ tumour necrosis factor $\alpha(\mathrm{TNF}-\alpha) 1^{-1}$ on cell proliferation by rat blastocysts incubated for $24 \mathrm{~h}$

\begin{tabular}{|c|c|c|c|c|c|c|c|}
\hline \multirow[b]{3}{*}{ Culture medium } & \multirow[b]{3}{*}{ Cell lineage } & \multicolumn{6}{|c|}{ Cell number } \\
\hline & & \multicolumn{2}{|c|}{ At start of incubation } & \multicolumn{4}{|c|}{ At end of incubation $(24 \mathrm{~h})$} \\
\hline & & Control & $\begin{array}{l}\text { Number } \\
\text { of embryos }\end{array}$ & Control & $\begin{array}{l}\text { Number } \\
\text { of cells }\end{array}$ & TNF- $\alpha$ & $\begin{array}{l}\text { Number } \\
\text { of embryos }\end{array}$ \\
\hline \multirow[t]{2}{*}{ Ham's F10 + BSA } & $\begin{array}{c}\text { ICM } \\
\text { TE }\end{array}$ & $\begin{array}{l}11.54 \pm 0.63 \\
22.46 \pm 0.77\end{array}$ & & $\begin{array}{l}18.96 \pm 0.75 \\
47.82 \pm 1.74\end{array}$ & & $\begin{array}{l}16.04 \pm 0.76^{b} \\
44.12 \pm 1.62\end{array}$ & \\
\hline & Total & $34.34 \pm 1.23$ & 24 & $66.73 \pm 2.24$ & 22 & $60.15 \pm 2.25^{a}$ & 26 \\
\hline \multirow[t]{2}{*}{ Ham's F10 + PVP } & $\begin{array}{l}\text { ICM } \\
\text { TE }\end{array}$ & $\begin{array}{l}12.93 \pm 0.57 \\
24.46 \pm 1.07\end{array}$ & & $\begin{array}{l}17.42 \pm 0.56 \\
50.50 \pm 1.22\end{array}$ & & $\begin{array}{l}15.76 \pm 0.53^{\mathrm{a}} \\
45.47 \pm 1.13^{\mathrm{b}}\end{array}$ & \\
\hline & Total & $37.68 \pm 1.53$ & 45 & $68.06 \pm 1.53$ & 50 & $61.22 \pm 1.35^{\mathrm{b}}$ & 45 \\
\hline
\end{tabular}

Results are given as means \pm SEM.

The superscripts $\mathrm{a}$ and $\mathrm{b}$ indicate significant differences between control and TNF- $\alpha$-treated groups at $P<0.05$ and $P<0.01$, respectively.

ICM: inner cell mass; PVP: polyvinylpyrrolidone; TE: trophectoderm cells.

To analyse these embryos further, the number of cells was counted at the start of the incubation period and after $24 \mathrm{~h}$ in the presence or absence of $3 \mathrm{nmol}$ TNF $-\alpha 1^{-1}$ (Table 2). In control medium supplemented with BSA, the total number of cells doubled during the culture to reach an average of 67 cells per blastocyst. There were $10 \%$ fewer cells in blastocysts that had been grown in the presence of TNF- $\alpha(P<0.05)$. This decrease amounted to $15.4 \%$ in the inner cell mass and $7.8 \%$ in the trophectoderm cells when calculated separately. When embryos were cultured in a medium supplemented with polyvinylpyrrolidone instead of BSA, the overall decrease induced by $3 \mathrm{nmol}$ TNF- $\alpha 1^{-1}$ in the total number of cells was of the same order of magnitude $(P<0.01)$, but the cellular deficiency was evenly distributed between the inner cell mass and the trophectoderm cells. The negative effect of TNF- $\alpha$ was fully neutralized by an anti-TNF- $\alpha$ antibody, since its addition in 500-fold molar excess corrected the cell distribution shift induced by TNF- $\alpha$ (Fig. 3). Anti-TNF- $\alpha$ antiserum or normal serum IgG had no effect on blastocyst proliferation when used alone at the same excess concentration (data not shown).

To ascertain whether the inhibitory effect of TNF- $\alpha$ could be reproduced at more physiological concentrations, the cell proliferation experiments were repeated using a culture medium supplemented with polyvinylpyrrolidone and 30 or 300 pmol TNF- $\alpha 1^{-1}$ in addition to the previous dose of $3 \mathrm{nmol} 1^{-1}$. In the presence of $30 \mathrm{pmol}$ TNF- $\alpha \mathrm{I}^{-1}$, the total number of cells was decreased by $9 \%$, with $12 \%$ of the difference occurring in the inner cell mass and $8 \%$ in the trophectoderm cells; the same results were obtained with $300 \mathrm{pmol} \mathrm{l}^{-1}(P<0.05)$ (Fig. 4). The morphology of the blastocysts was not modified by TNF- $\alpha$ at any of the three doses. The data therefore indicated that the maximal inhibition of cell proliferation by TNF- $\alpha$ was probably about $10 \%$ in rat blastocysts and that this effect could be achieved in vitro with 30 pmol TNF- $\alpha 1^{-1}$.

To determine whether the cellular deficiency associated with TNF- $\alpha$ was mediated by the cytostatic or cytotoxic properties Downloaded from Bioscientifica.com at 04/26/2023 11:30:40A 


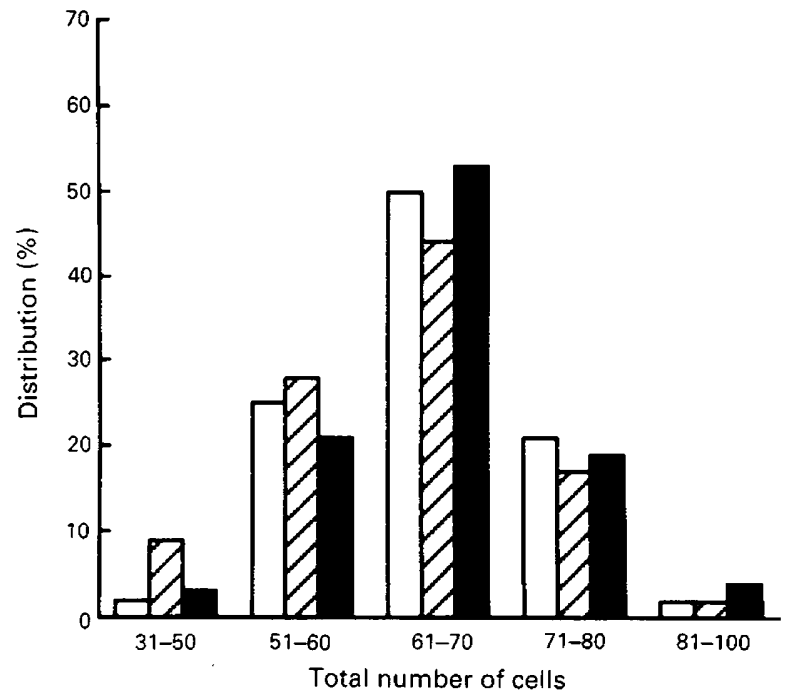

Fig. 3. Neutralization of the decrease in number of cells induced by tumour necrosis factor $\alpha$ (TNF- $\alpha$ ) in rat blastocysts. Embryos were incubated in control medium $(\square)$, with $3 \mathrm{nmol}$ TNF- $\alpha 1^{-1}(\mathbb{Z})$ or with $3 \mathrm{nmol}$ TNF- $\alpha 1^{-1}$ neutralized with an anti-TNF- $\alpha$ antibody ( $\boldsymbol{\square}$ ), and the total number of cells was counted after $24 \mathrm{~h}$. The distribution pattern, shifted to the left following exposure to TNF- $\alpha(P<0.05)$ was corrected by neutralizing the cytokine. More than 50 blastocysts were tested in each group.

of the cytokine, preparations of blastocysts exposed to $3 \mathrm{nmol}$ TNF- $\alpha \mathrm{I}^{-1}$ for $24 \mathrm{~h}$ were carefully analysed for the presence of dead cells in the inner cell mass and trophectoderm cell lineages (Table 3). Dead cells were identified by their scattered arrays of irregular nuclear fragments. Although there was a clear increase in both inner cell mass and trophectoderm dead cell indices following culture for $24 \mathrm{~h}$ compared with initial values, addition of $3 \mathrm{nmol}$ TNF- $\alpha 1^{-1}$ did not modify these proportions in a significant manner. Comparable results were obtained irrespective of whether BSA or polyvinylpyrrolidone was added to the culture medium.

\section{Glucose metabolism}

Blastocysts were cultured for $4 \mathrm{~h}$ in the presence or absence of $3 \mathrm{nmol}$ TNF- $\alpha \mathrm{I}^{-1}$ and assessed for glucose utilization (Fig. 5). Addition of TNF- $\alpha$ at that concentration failed to modify the rate of glucose consumption through the glycolytic pathway, but decreased the rate of incorporation of glucosederived compounds into blastocysts $(P<0.05)$.

\section{Discussion}

The study reported here was designed to determine whether rat blastocysts are a potential target for TNF- $\alpha$ when they are preparing for their implantation in the uterus. Previous reports have demonstrated that uterine epithelial and decidual cells are primary sites of TNF- $\alpha$ synthesis during early pregnancy in rats (Yelavarthi et al., 1991), and similar results have been obtained when both mouse and human reproductive tissues were investigated during the same gestational

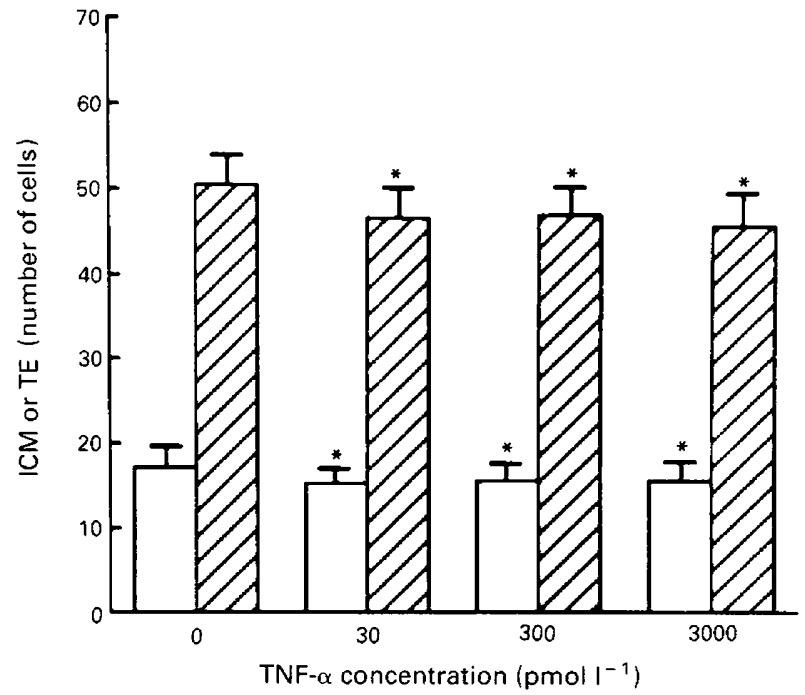

Fig. 4. Influence of different doses of tumour necrosis factor $\alpha$ (TNF- $\alpha$ ) on cell proliferation by rat blastocysts. Embryos were incubated in control medium or with increasing concentrations of TNF- $\alpha$, and the number of inner cell mass cells (ICM) ( $\square$ ) and the number of trophectoderm cells (TE) $(\square)$ were counted after $24 \mathrm{~h}$. More than 40 embryos were tested in each group and the results are given as means \pm SEM. ${ }^{*}$ Differences between control embryos and TNF- $\alpha$-treated embryos were statistically significant $(P<0.05)$ for both number of ICM cells and number of TE cells at the three doses tested.

period (Chen et al., 1991; Hunt et al., 1993). Transient increases in both mRNA and protein content have been detected for TNF- $\alpha$ on day 1 of pregnancy and during the peri-implantation period in the mouse uterus (Sanford et al., 1992; De et al., 1993).

The aim of the first part of our investigation was to determine whether rat blastocysts express TNF- $\alpha$ receptors. ${ }^{125}$ I-labelled TNF- $\alpha$ binding was observed on the cell surface of blastocysts and this ligand binding was eliminated in the presence of competing unlabelled TNF- $\alpha$. Displacement of ${ }_{125}$ I-labelled TNF- $\alpha$ by lymphotoxin $\alpha$ (TNF- $\beta$ ), which also binds to TNF- $\alpha$ receptors (Schoenfeld et al., 1991), was not investigated because there has been no published evidence of lymphotoxin $\alpha$ synthesis in the pregnant uterus. The expression of TNF- $\alpha$ receptors by rat blastocysts was further supported by the detection of corresponding mRNAs using the reverse transcription-PCR technique. Although two distinct TNF- $\alpha$ receptors have been identified in mice (Goodwin et al., 1991; Lewis et al., 1991) and in humans (Fiers, 1991; Vassalli, 1992), only one of these receptors (TNF- $\alpha$ Rp60) has been molecularly cloned in rats (Himmler et al., 1990). Reverse transcription-PCR analysis of different batches of embryos indicated that at least the TNF- $\alpha$ Rp 60 form is expressed in rat embryos at the blastocyst stage. The two TNF- $\alpha$ receptors that have been characterized in other species are known to initiate distinct signal transduction pathways in responsive cells, and recent comparative studies have demonstrated the predominant role of the TNF- $\alpha$ p 60 receptor over the Rp80 form in many cellular systems (Tartaglia et al., 1991). It is possible that rat embryos co-express both TNF- $\alpha$ receptor forms during the Downloaded from Bioscientifica.com at 04/26/2023 11:30:40AM 
Table 3. Effect of $3 \mathrm{nmol}$ tumour necrosis factor $\alpha$ (TNF- $\alpha) 1^{-1}$ on dead cell indices in rat blastocysts incubated for $24 \mathrm{~h}$

Dead cell index $(\%)$

\begin{tabular}{|c|c|c|c|c|c|c|c|}
\hline \multirow[b]{3}{*}{ Culture medium } & \multirow[b]{3}{*}{ Cell lineage } & \multirow{2}{*}{\multicolumn{2}{|c|}{ At start of incubation }} & & & & \\
\hline & & & & \multicolumn{4}{|c|}{ At end of incubation $(24 \mathrm{~h})$} \\
\hline & & Control & $\begin{array}{c}\text { Number } \\
\text { of embryos }\end{array}$ & Control & $\begin{array}{l}\text { Number } \\
\text { of embryos }\end{array}$ & TNF- $a$ & $\begin{array}{c}\text { Number } \\
\text { of embryos }\end{array}$ \\
\hline \multirow[t]{3}{*}{ Ham's F10 + BSA } & $\mathrm{ICM}$ & $\leq 0.50$ & & $5.07 \pm 1.84$ & & $7.27 \pm 1.43$ & \\
\hline & $\mathrm{TE}$ & $\leq 0.50$ & & $1.17 \pm 0.61$ & & $0.66 \pm 0.35$ & \\
\hline & Whole embryo & $\leq 0.50$ & 24 & $2.17 \pm 0.57$ & 22 & $2.36 \pm 0.50$ & 26 \\
\hline \multirow[t]{3}{*}{ Ham's F10 + PVP } & ICM & $\leq 0.50$ & & $6.84 \pm 1.49$ & & $4.35 \pm 0.92$ & \\
\hline & $\mathrm{TE}$ & $\leq 0.50$ & & $\leq 0.50$ & & $\leq 0.50$ & \\
\hline & Whole embryo & $\leq 0.50$ & 45 & $1.67 \pm 0.34$ & 50 & $1.35 \pm 0.27$ & 45 \\
\hline
\end{tabular}

Results are given as means \pm SEM.

ICM: inner cell mass; PVP: polyvinylpyrrolidone; TE: trophectoderm cells.
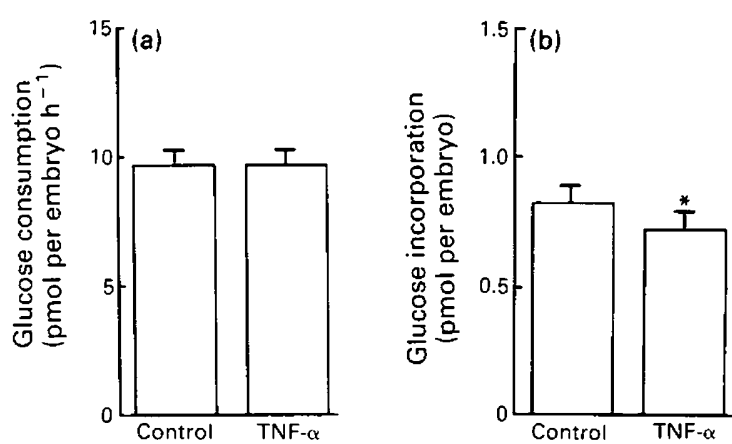

Fig. 5. Influence of tumour necrosis factor $\alpha$ (TNF- $\alpha$ ) on the rates of glucose consumption and incorporation by rat blastocysts. (a) Embryos were incubated in control medium (control) or with $3 \mathrm{nmol}$ TNF- $\alpha 1^{-1}$ (TNF- $\alpha$ ) in the presence of $\mathrm{D}-\left[5-{ }^{3} \mathrm{H}\right] \mathrm{glucose}$ and tested for their glucose consumption after $4 \mathrm{~h}$, as measured by the quantitative recovery of ${ }^{3} \mathrm{H}_{2} \mathrm{O}$ in a $\mathrm{NaOH}$ chemical trap. (b) At the end of the incubation period, the embryos were washed and assessed for the incorporation of glucose. Control and TNF- $\alpha$ results were significantly different from each other $\left({ }^{*} P<0.05\right)$. More than 50 batches of three embryos were tested in each group and the results are given as means \pm SEM.

preimplantation period but, if earlier observations in the mouse are of any relevance, this seems unlikely. Previous studies have indeed shown that only the p60 form of the TNF- $\alpha$ receptor, and not the $\mathrm{p} 80$ form, is expressed in early post-implantation embryos (Goodwin et al., 1991) and this comparison has recently been extended to the preimplantation period ( $R$. De Hertogh, Y-D. Wun and S. Pampfer, unpublished).

Once the presence of TNF- $\alpha$ receptors on rat embryos was established, their function was studied by examining different developmental parameters in blastocysts following their incubation for $24 \mathrm{~h}$ with TNF- $\alpha$. Concentrations of about $25 \mathrm{pmol}^{-1}$ have been detected in human follicular fluids (Wang et al., 1992) and in peritoneal fluids associated with endometriosis (Taketani et al., 1992). Circulating concentrations of TNF- $\alpha$ in obese rats can reach $10 \mathrm{pmol}^{-1}$ (Hotamisligil et al., 1993) and previous experiments demonstrating the action of TNF- $\alpha$ on rat placental and ovarian cells were carried out with doses from $0.01 \mathrm{nmol}^{-1}$ to $50 \mathrm{nmol} \mathrm{l}^{-1}$ (Hunt et al., 1989, 1990; Andreani et al., 1991; Zachow et al., 1992; Brännström et al., 1993). In the study reported here, doses of 30 and $300 \mathrm{pmol} \mathrm{l}^{-1}$, and $3 \mathrm{nmol} \mathrm{TNF-} \alpha \mathrm{l}^{-1}$ were tested on rat blastocysts. Incubations were performed in a culture medium supplemented with either BSA or a synthetic macromolecule (polyvinylpyrrolidone) (Cholewa and Whitten, 1970) because commercially available BSA preparations sometimes contain co-purified contaminants that might interfere with the experiments (Gardner and Kaye, 1991).

The three different TNF- $\alpha$ doses significantly inhibited the rate of cell proliferation in rat blastocysts, without affecting their morphological appearance. The extent of this inhibition was approximately $10 \%$ of the total number of cells and equally distributed between the two embryonic cell lineages studied (the inner cell mass and trophectoderm cells). These two cellular populations are known to contribute to distinct embryonic components following implantation, with the inner cell mass cells giving rise to all of the fetal germ layers and the trophectoderm cells participating in the formation of the embryo-maternal interface (Hebel and Stromberg, 1986). Although the extent of the cellular decrease induced by TNF- $\alpha$ is small, it is important to consider that any cell loss caused by arrested cell multiplication or cell death in the inner cell mass lineage before implantation will result in a much larger deficiency a few cell divisions later, when this type of cell is expected to form the primitive egg cylinder. Previous experimental studies have clearly demonstrated that failure to provide enough inner cell mass cells prior to this critical developmental phase was incompatible with a successful postimplantation embryogenesis, even when placental derivatives appeared normal (Tam, 1988).

Our data suggest that an early exposure to a physiological dose of TNF- $\alpha$ may diminish the ability of rat blastocysts to generate viable fetuses. It should also be remembered that TNF- $\alpha$ often needs to synergize with other cytokines to Downloaded from Bioscientifica.com at 04/26/2023 11:30:40AM 
achieve full efficiency (Fiers, 1991; Vassalli, 1992) and that many of these co-factors are secreted by uterine cells during the preimplantation period (Pampfer $e t$ al., 1991). Surprisingly, the inhibitory effect of TNF- $\alpha$ on cell proliferation was apparently not mediated by a marked increase in the occurrence of cell death, suggesting that TNF- $\alpha$ is embryostatic rather than embryotoxic on early rat embryos when tested in the absence of other factors.

As a preliminary step towards understanding how TNF- $\alpha$ could mediate its action on preimplantation embryonic growth, the possibility that TNF- $\alpha$ may alter glucose metabolism was investigated in blastocysts. Rat embryos at this stage have recently been shown to take up and use glucose actively, mostly through the glycolytic metabolic pathway, during the blastocyst phase (Brison and Leese, 1991; Dufrasnes et al., 1993). Insulin, which can modulate cell proliferation in rat blastocysts in vitro (De Hertogh et al., 1991), was found to do so without affecting glucose metabolism (Dufrasnes et al, 1993). At concentrations within the $1-10 \mathrm{nmol} \mathrm{l}^{-1}$ range, TNF- $\alpha$ stimulates glucose uptake in cell types such as muscle cells (Lee et al., 1987), fibroblasts (Cornelius et al., 1990) and vascular endothelial cells (Pekala et al., 1990). In these cells, the effect of TNF- $\alpha$ was mediated through the upregulation of type-1 glucose transporters, a form of the $\mathrm{Na}^{+}$-independent glucose transporter family that is also present in mouse preimplantation embryos (Hogan et al., 1991; Aghayan et al., 1992). To test whether TNF- $\alpha$ could interfere with embryonic glucose metabolism, blastocysts were cultured in the presence of $3 \mathrm{nmol}$ TNF- $\alpha \mathrm{l}^{-1}$ and $\mathrm{D}-\left[5-{ }_{-}^{3} \mathrm{H}\right] \mathrm{glucose}$ during a period that was too short to allow the cytokine to affect embryonic cell proliferation. TNF- $\alpha$ did not modify the rate of glycolysis in the treated embryos but decreased the incorporation of radiolabelled glucose into macromolecules. Because TNF- $\alpha$ can also enhance the rate of glycogen breakdown in muscle cells (Lee et al., 1987), these results suggest a possible association between TNF- $\alpha$ and the pattern of glycogen accumulation in rat blastocysts.

TNF- $\alpha$ is presumably one of the most pleiotropic cytokines to have been characterized so far, and its implication in several biological mechanisms involved in the host defence against infection and cancer means that its synthesis must be vital in many instances. Clearly, such a critical status has severe drawbacks when it becomes unbalanced, and it is now well established that TNF- $\alpha$ can also induce extremely deleterious effects when released in an inappropriate dose with respect to time (Fiers, 1991; Vassalli, 1992). Previous demonstrations that TNF- $\alpha$ is locally synthesized in the pregnant uterus along with the data presented here raise interesting questions as to the role of this cytokine in the regulation of early pregnancy.

This research was financed by grants from the Fund for Medical Scientific Research and from the Fund for Scientific Development of Belgium, from the National Fund for Scientific Research of Belgium (to S. Pampfer) and from the Juvenile Diabetes Foundation International.

\section{References}

Aghayan M, Rao LV, Smith RM, Jarett L, Charron MJ, Thorens B and Heyner S (1992) Developmental expression and cellular localization of glucose transporter molecules during mouse preimplantation development Development 115 305-312
Andreani CL, Payne DW, Packman JN, Resnick CE, Hurwitz A and Adashi EY (1991) Cytokine-mediated regulation of ovarian function: tumor necrosis factor- $\alpha$ inhibits gonadotropin-supported ovarian androgen biosynthesis Journal of Biological Chemistry 266 6761-6766

Bernardini R, Kamilaris TC, Calogero AE, Johnson EO, Gomez MT, Gold PW and Chrousos GP (1990) Interactions between tumor necrosis factor- $\alpha$, hypothalamic corticotropin-releasing hormone and adrenocorticotropin secretion in the rat Endocrinology 126 2876-2881

Brännström M, Wang L and Norman RJ (1993) Effects of cytokines on prostaglandin production and steroidogenesis of incubated preovulatory follicles of the rat Biology of Reproduction 48 165-171

Brison DR and Leese HJ (1991) Energy metabolism in late preimplantation rat embryos Journal of Reproduction and Fertility 93 245-251

Carswell EA, Old LJ, Kassel RL, Green S, Fiore N and Williamson B (1975) An endotoxin-induced serum factor that causes necrosis of tumors Proceedings of the National Academy of Sciences USA 72, 3666-3670

Chen HL, Yang XL, Yelavarthi KK, Fishback JL and Hunt JS (1991) Tumor necrosis factor- $\alpha$ mRNA and protein are present in human placental and uterine cells at early and late stages of gestation American Journal of Pathology 139 327-335

Cholewa JA and Whitten WK (1970) Development of 2-cell mouse embryos in the absence of a fixed nitrogen source Journal of Reproduction and Fertility $\mathbf{2 2}$ 553-555

Chomczynski P and Sacchi N (1987) Single-step method of RNA isolation by acid guanidium thiocyanate-phenol-chloroform extraction Analytical Biochemistry 162 156-159

Cornelius P, Marlowe M, Lee MD and Pekala PH (1990) The growth factor-like effect of tumor necrosis factor- $\alpha$ : stimulation of glucose transport activity and induction of glucose transporter and immediate early gene expression in 3T3-L1 preadipocytes Journal of Biological Chemistry 265 20506-20516

Davis LG, Dibner MD and Battey JF (1989) In situ hybridization of labeled probes to tissue sections. In Basic Methods in Molecular Biology, pp 355-359. Elsevier Science Publishers, New York

De M, Sanford TR and Wood GW (1993) Expression of interleukin-1, interleukin- 6 and tumor necrosis factor- $\alpha$ in mouse uterus during the peri-implantation period of pregnancy Joumal of Reproduction and Fertility 97 83-89

De Hertogh R, Vanderheyden I, Pampfer S, Robin D, Dufrasnes E and Delcourt J (1991) Stimulatory and inhibitory effects of glucose and insulin on rat blastocyst development in vitro Diabetes 40 641-647

Dufrasnes E, Vanderheyden I, Robin D, Delcourt J, Pampfer S and De Hertogh R (1993) Glucose and pyruvate metabolism in preimplantation blastocysts from normal and diabetic rats Journal of Reproduction and Fertility 98 169-177

Fiers $W$ (1991) Tumor necrosis factor: characterization at the molecular, cellular and in vivo level FEBS Letters 285 199-212

Gardner HG and Kaye PL (1991) Insulin increases cell number and morphological development in mouse preimplantation embryos in vitro Reproduction Fertility and Development 3 79-91

Gates AH (1965) Rate of ovular development as a factor in embryonic survival In The Mouse: its Reproduction and Development, pp 56-57 Ed. R Rugh. Burges Publishing, New York

Giroir BP, Johnson JH, Brown T, Allen GL and Beutler B (1992) The tissue distribution of tumor necrosis factor biosynthesis during endotoxemia Joumal of Clinical Investigation $90693-698$

Goodwin RG, Anderson D, Jerzy R, Davis T, Brannan CI, Copeland NG Jenkins NA and Smith CA (1991) Molecular cloning and expression of type 1 and type 2 murine receptors for tumor necrosis factor Molecular and Cellular Biology 11 3020-3026

Haimovici F, Hill JA and Anderson DJ (1991) The effects of soluble products of activated lymphocytes and macrophages on blastocyst implantation events in vitro Biology of Reproduction 44 69-75

Hebel R and Stromberg MW (1986) Embryology. In Anatomy and Embryology of the Laboratory Rat, pp 231-267. Williams and Wilkins Publishing, Baltimore

Hill JA, Haimovici F and Anderson DJ (1987) Products of activated lymphocytes and macrophages inhibit mouse embryo development in vitro journal of Immunology 139 2250-2254

Himmler A, Maurer-Fogy I, Kroenke M, Scheurich P, Pfizenmaier K, Lantz M, Olsson I, Hauptmann R, Stratowa C and Adolf GR (1990) Molecular cloning and expression of human and rat tumor necrosis factor receptor chain (p60) and its soluble derivative, tumor necrosis factor-binding protein DNA and Cell Biology 9 705-715

Downloaded from Bioscientifica.com at 04/26/2023 11:30:40AM 
Hogan A, Heyner S, Charron MJ, Copeland NG, Gilbert D, Jenkins NA, Thorens B and Schultz GA (1991) Glucose transporter gene expression in early mouse embryos Development 113 363-372

Hotamisligil GS, Shargill NS and Spiegelman BM (1993) Adipose expression of tumor necrosis factor- $\alpha$ : direct role in obesity-linked insulin resistance Science 259 87-91

Hunt IS, Soares MJ, Lei MG, Smith RN, Wheaton D, Atherton RA and Morrison DC (1989) Products of lipopolysaccharide-activated macrophages (tumor necrosis factor- $\alpha$ and transforming growth factor- $\beta$ ) but not lipopolysaccharide modify DNA synthesis by rat trophoblast cells exhibiting the $80 \mathrm{kDa}$ lipopolysaccharide-binding protein Joumal of Immunology 143 1606-1613

Hunt JS, Atherton RA and Pace JL (1990) Differential response of rat trophoblast cells and embryonic fibroblasts to cytokines that regulate proliferation and class I MHC antigen expression Journal of Immunology 145 184-189

Hunt JS, Chen HL, Hu XL and Pollard JW (1993) Normal distribution of tumor necrosis factor- $\alpha$ messenger ribonucleic acid and protein in the uteri, placentas and embryos of osteopetrotic (op/op) mice lacking colony stimulating factor-1 Biology of Reproduction 49 441-452

Lachapelle MH, Miron P, Hemmings R, Falcone T, Granger L, Bourque J and Langlais J (1993) Embryonic resistance to tumor necrosis factor- $\alpha$ mediated cytotoxicity: novel mechanism underlying maternal immunological tolerance to the fetal allograft Human Reproduction 7 1032-1038

Lee MD, Zentella A, Pekala PH and Cerami A (1987) Effect of endotoxin-induced monokines on glucose metabolism in the muscle cell line L6 Proceedings of the National Academy of Sciences USA 84 2590-2594

Lewis M, Tartaglia LA, Lee A, Bennett GL, Rice GC, Wong GH, Chen EY and Goeddel DV (1991) Cloning and expression of CDNAs for two distinct murine tumor necrosis factor receptors demonstrate one receptor is species specific Proceedings of the National Academy of Sciences USA $\mathbf{8 8} 2830-2834$

Männel DN, Moore RN and Mergenhagen SE (1980) Macrophages as a source of tumoricidal activity (tumor necrotizing factor) Infection and Immunity 30 523-530

Miller SC, Ito H, Blau HM and Torti FM (1988) Tumor necrosis factor inhibits human myogenesis in vitro Molecular and Cellular Biology 8 2295-2301

Nudel U, Zakut R, Shani M, Neuman S, Levy Z and Yaffe D (1983) The nucleotide sequence of the rat cytoplasmic $\boldsymbol{\beta}$-actin gene Nucleic Acids Research 11 1759-1771

Pampfer S, Vanderheyden I, Michiels B and De Hertogh R (1990) Cell allocation to the inner cell mass and the trophectoderm in rat embryos during in vivo preimplantation development Roux's Archives of Developmental Biology 198 257-263

Pampfer S, Arceci RJ and Pollard JW (1991) Role of colony stimulating factor-1 and other lympho-hematopoietic growth factors in mouse preimplantation development Bioessays 13 535-540

Pampfer S, Fan W, Schubart UK and Pollard JW (1992) Differential mRNA expression of the phosphoprotein p19/SCG10 gene family in mouse preimplantation embryos, uterus and placenta Reproduction Fertility and Development 4 205-211

Paria BC and Dey SK (1990) Preimplantation embryo development in vitro: cooperative interactions among embryos and role of growth factors Proceedings of the National Academy of Sciences USA 87 4756-4760

Pekala PH, Marlow M, Heuvelman D and Connolly D (1990) Regulation of hexose transport in aortic endothelial cells by vascular permeability factor and tumor necrosis factor- $\alpha$, but not by insulin Journal of Biological Chemistry 265 18051-18054
Price SR, Olivecrona T and Pekala PH (1986) Regulation of lipoprotein lipase synthesis by recombinant tumor necrosis factor: the primary regulatory role of the hormone in 3T3-L1 adipocytes Archives of Biochemistry and Biophysics $251738-746$

Roby KF and Terranova PF (1989) Localization of tumor necrosis factor (TNF) in the rat and bovine ovary using immunocytochemistry and cell blot: evidence for granulosal production. In Growth Factors and the Ovary pp 273-278 Ed. AN Hirshfield. Plenum Publishing, New York

Sancho-Tello M, Perez-Roger I, Imakawa K, Tilzer L and Terranova PF (1992) Expression of tumor necrosis factor- $\alpha$ in the rat ovary Endocrinology 130 1359-1364

Sanford TR, De M and Wood GW (1992) Expression of colony stimulating factors and inflammatory cytokines in the uterus of CD1 mice during days 1 to 3 of pregnancy journal of Reproduction and Fertility 94 213-220

Schoenfeld HJ, Poeschl B, Frey JR, Loetscher HR, Hunziker W, Lustig A and Zulauf M (1991) Efficient purification of recombinant human tumor necrosis factor beta from $E$. coli yields biologically active protein with a trimeric structure that binds to both tumor necrosis factor receptors Journal of Biological Chemistry 266 3863-3869

Selmaj KW and Raine CS (1988) Tumor necrosis factor mediates myelin and oligodendrocyte damage in vitro Annals of Neurology 23 339-345

Taketani Y, Kuo TM and Mizuno M (1992) Comparison of cytokine levels and embryo toxicity in peritoneal fluid in infertile women with untreated or treated endometriosis American Joumal of Obstetrics and Gynecology 167 265-270

Tam PL (1988) Post-implantation development of mitomycin C-treated mouse blastocysts Teratology 37 205-212

Tartaglia LA, Weber RF, Figari IS, Reynolds C, Palladino MA and Goeddel DV (1991) The two different receptors for tumor necrosis factor mediate distinct cellular responses Proceedings of the National Academy of Sciences USA 88 9292-9296

Vassalli P (1992) The pathophysiology of tumor necrosis factor Annual Review of Immunology 10 411-452

Vilcek J, Palombella VJ, Henriksen-DeStefano D, Swenson C, Feinman R, Hirai M and Tsujimoto $M$ (1986) Fibroblast growth enhancing activity of tumor necrosis factor and its relationship to other polypeptide growth factors Journal of Experimental Medicine $163632-643$

Wang LJ, Brännström M, Robertson SA and Norman RJ (1992) Tumor necrosis factor- $\alpha$ in the human ovary: presence in follicular fluid and effect on cell proliferation and prostaglandin production Ferility and Sterility $\mathbf{5 8} 934-940$

Wincek TJ, Meyer TK, Meyer MR and Kuehl TJ (1991) Absence of a direct effect of recombinant tumor necrosis factor- $\alpha$ on human sperm function and murine preimplantation development Fertility and Sterility 56 332-339

Yelavarthi KK, Chen HL, Yang Y, Cowley BD, Fishback JL and Hunt JS (1991) Tumor necrosis factor- $\alpha$ mRNA and protein in rat uterine and placental cells Journal of Immunology 146 3840-3848

Zachow RJ, Tash JS and Terranova PF (1992) Tumor necrosis factor- $\alpha$ induces clustering in ovarian theca-interstitial cells in vitro Endocrinology 131 2503-2513 